Ozturk, A., et al., Performances of Popcorn Hybrids in Three Geographical Regions of Turkey Based on Yield and Quality Traits. International Journal of Life Sciences and Biotechnology, 2020. 3(1): p. 27-40. DOI: $10.38001 /$ ijlsb.646400

\title{
Performances of Popcorn Hybrids in Three Geographical Regions of Turkey Based on Yield and Quality Traits
}

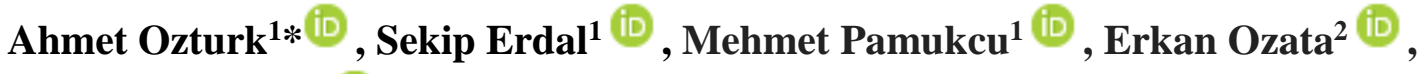 \\ Yalcin Coskuner ${ }^{3}$ (iD
}

\begin{abstract}
Evaluation of popcorn experimental hybrids in different geographical regions gives valuable clues to breeders in selection of best hybrids for the target environments. In the present study, 49 popcorn crosses (44 test hybrids and 5 commercial checks) were tested in three different ecological condition in Turkey. A $7 \times 7$ lattice design using three replications were used. The field experiments of this research was carried out in Samsun (Northern Turkey), Çankırı (Middle Anatolia) and Antalya (South Anatolia) ecological conditions in 2016. Yield and quality parameters such as popping volume, unpopped kernels ratio and kernel size were determined. According to the results, 10 hybrids have a high performance over than 5 commercial checks. Yield and quality results showed that TBCM2015-41, 56, 62, 76 and 80 candidate hybrids were promising popcorn hybrids for the tested environments.
\end{abstract}

\author{
ARTICLE HISTORY \\ Received \\ 13 November 2019 \\ Accepted \\ 21 January 2020 \\ KEY WORDS \\ Single cross, \\ performance, \\ popcorn, \\ popping volume, \\ quality traits
}

\section{Introduction}

Zea mays belongs to the Gramineae family (Wheatgrass) and is divided into seven sub groups. Among these groups popcorn has a special significance thanks to rich nutrient content, high vitamins and minerals [1]. Popcorn also is a prudent choice for those wanting to reduce feelings of hunger while managing energy intake and ultimately, body weight [2]. A major trait that distinguishes popping maize from other types of maize is a formation of large flake after kernel popping as a response to the heat treatment [3]. Popcorn, flint corn and dent corn are different each other by grain appearances. The most important observation in terms of seed differences is the shape and size of the seeds. Popcorn is smaller and has a thicker layer of endosperm than other two types. High quality hybrid popcorn must have high and stable yield and high level of popping volume [4].

\footnotetext{
${ }^{1}$ Batı Akdeniz Agricultural Research Institute, Antalya,Turkey

${ }^{2}$ Black Sea Agricultural Research Institute, Samsun,Turkey

${ }^{3}$ Karamanoglu Mehmetbey University Engineering Faculty Department of Food Engineering, Karaman, Turkey

*Corresponding author: ozturkahmet@tarimorman.gov.tr
} 
The popping volume (PV) is the most important parameter of quality and principal trait distinguishing popping maize from other types of maize [3]. Major quality characteristics of popcorn is high PV, a good appearance, low unpopped kernel rate and kernel size. Popcorn varieties traded in the world, consist of many different species in terms of seed color, size and seed shape. No industry standards have been developed for kernel size determinations; but a commonly used measure is based on number of kernel in 10 grams and defines kernel size as follow: 52-67= large, 68-75=medium and 76-105= small, $>105=$ very small $[5]$.

Turkey's popcorn cultivation has increased significantly in recent years. However, production is not enough for the demand of the country. Turkey imports popcorn as a result of insufficient production [6]. Popcorn agriculture is made with farmer contract ten thousand ha in Turkey. The consumption of popcorn is dramatically increased after 1980's depend on rise of shopping centers and cinema in Turkey [7]. Hybrids with high yield and quality are needed for the country.

The objective of this research was to determine new popcorn hybrids with high yield and quality which can meet the demands not only producers but also consumers.

\section{Materials and Methods}

In the present study, 44 experimental hybrids plus 5 commercial checks total 49 popcorn crosses were tested in three regions of Turkey. The research was carried out in Antalya Bati Akdeniz Agricultural Research Institute (BATEM) (36053' N, 30042' Mediterranean of Turkey), Samsun Black Sea Agricultural Research Institute (KTAE) (41016' N, 36020' Northern Turkey) and Çankırı Karatekin University (40032'N, 33035' Middle Anatolia) ecological conditions in 2016. The meteorological conditions of locations during growing seasons are shown in Table 1. Hybrid seeds obtained from three locations were also used for quality analysis.

Tablo 1 The meteorological conditions of locations during growing season of 2016

\begin{tabular}{|l|l|l|l|l|l|l|}
\hline & \multicolumn{3}{|c|}{ Antalya } & \multicolumn{2}{c|}{ Samsun } & \multicolumn{2}{c|}{ Çankır1 } \\
\hline & $\begin{array}{l}\text { Temperature } \\
\left({ }^{\circ} \mathrm{C}\right)\end{array}$ & $\begin{array}{l}\text { Precipitatio } \\
\mathrm{n}(\mathrm{mm})\end{array}$ & $\begin{array}{l}\text { Temperatur } \\
\mathrm{e}\left({ }^{\circ} \mathrm{C}\right)\end{array}$ & $\begin{array}{l}\text { Precipitation } \\
(\mathrm{mm})\end{array}$ & $\begin{array}{l}\text { Temperat } \\
\text { ure }\left({ }^{\circ} \mathrm{C}\right)\end{array}$ & $\begin{array}{l}\text { Precipitatio } \\
\mathrm{n}(\mathrm{mm})\end{array}$ \\
\hline April & 18.2 & 11.0 & 13.7 & 44.4 & 12.2 & 52.5 \\
\hline May & 20.3 & 15.0 & 16.3 & 191.8 & 16.5 & 57.0 \\
\hline
\end{tabular}




\begin{tabular}{|l|l|l|l|l|l|l|}
\hline June & 26.1 & 18.0 & 21.4 & 98.5 & 22.0 & 50.2 \\
\hline July & 29.1 & 0.0 & 23.5 & 50.9 & 24.3 & 22.5 \\
\hline August & 26.6 & 0.0 & 24.7 & 59.0 & 23.2 & 20.2 \\
\hline September & 24.6 & 24.0 & 19.5 & 108.2 & 20.2 & 18.5 \\
\hline October & 21.3 & 5.0 & 14.6 & 39.6 & 12.5 & 31.7 \\
\hline November & 14.7 & 78.0 & 10.6 & 94.3 & 7.8 & 35.8 \\
\hline $\begin{array}{l}\text { Avaerage/ } \\
\text { Sum }\end{array}$ & 22.6 & 151.0 & 18.04 & 686.7 & 17.34 & 288.4 \\
\hline
\end{tabular}

The field experiments were conducted in a $7 \times 7$ lattice design with three replications. Plots consisted of two rows. Row length was $5.0 \mathrm{~m} .0 .18 \mathrm{~m}$ and $0.70 \mathrm{~m}$ were used as on row and inter row distances, respectively. All cultural practice used in the experiments were as follow; Fertilizing was made as pure $8 \mathrm{~kg}$ phosphorus and $20 \mathrm{~kg}$ N/ha totally per decare according to soil analysis. All phosphorus and $8 \mathrm{~kg} / \mathrm{ha}$ of nitrogen were given at the time of sowing as bottom fertilizer, the rest of the nitrogenous fertilizer was applied in four equal parts using drip irrigation system. Planting of popcorn seeds were done in 10th of April in Antalya location, in 2nd of May in Samsun location, in 18th of May in Çankırı location. Crops were harvested on September 20-22 in Antalya location, on October 2022 in Samsun location, on November 1-2 in Çankırı location. The harvesting process was done manually on different dates because of plants reached to harvesting status at different dates. Experiment plots were harvested, measured and adjusted to $15 \%$ kernel moisture content to obtain grain yield (GY). Below formula was used for determination of GY. GY= Plot weight $\times$ [(100- grain moisture \% /85) x $(($ Grain / ear ratio $) / 100)]$ Popping volume (PV), unpopped kernels ratio (UKR), kernel size (KS) traits were examined in Karamanoglu Mehmetbey University Food Engineering Department Laboratory in 2017. PV ( $\left.\mathrm{cm}^{3} \mathrm{~g}-1\right)$ was determined according to methods described [8]. A hot air popping machine was used for PV. The moisture content of samples was $10 \pm 0.5 \%$ before popping. Popped samples were poured into a $2000 \mathrm{~mL}$ plastic graduated cylinder, and volume recorded [6]. The method described by [9] was used for UKR (\%). For UKR, before and after popping, the number of kernels for each sample was counted according to following formula. Percentage of unpopped kernel ratio= (Number of total unpopped kernels / Original number of kernels) $\times 100$. KS (number/10g) was measured according to [5]. All data obtained within this study was analyzed according to ANOVA procedures. 
The multiple comparison of the group averages were made according to LSD multiple range tests.

\section{Results}

The difference between genotypes, locations and genotype by environment interactions for GY, PV, UKR, KS traits were found statistically significant at P <0.01 (Table 2). Due to significant environmental interaction, the locations were evaluated separately (Supplementary Table 3).

Table 2 Analysis of variance (ANOVA) for investigated traits

\begin{tabular}{llllll}
\hline Source & DF & GY & PV & UKR & KS \\
\hline Blok(Rep) & 18 & 0.7315 & 0.0863 & 0.2046 & 0.4108 \\
Replication & 2 & 0.0061 & $<.0001$ & 0.2450 & 0.5602 \\
Location & 2 & $<.0001$ & $<.0001$ & $<.0001$ & $<.0001$ \\
Genotype & 48 & $<.0001$ & $<.0001$ & $<.0001$ & $<.0001$ \\
Genotype x location & 96 & $<.0001$ & $<.0001$ & $<.0001$ & $<.0001$ \\
LSD & & 66.81 & 0.29 & 1.86 & 2.20 \\
CV $(\%)$ & & 11.79 & 1.23 & 10.63 & 2.74 \\
\hline
\end{tabular}

The mean performances of the 49 popcorn crosses were given in supplementary Table 3. The average GY of genotypes was found to be $4.18 \mathrm{t}$ ha- 1 , and it was varied between 1.91 t ha-1 (TBCM2015-86) and 6.75 t ha-1 (TBCM2015-56) in Antalya Location. Mean experiment yield in Çankırı location was $6.0 \mathrm{t}$ ha-1. Yields varied between $3.85 \mathrm{t}$ ha-1 (TBCM2015-61) and 7.39 t ha-1 (TBCM2015-80) in Çankırı site. Yields in Samsun location were changed between 4.52 t ha-1 (TBCM2015-99) and experiment average was 7.13 t ha-1 (TBCM2015-80) for this location (Supplementary Table 3).

The mean of PV of genotypes was found as $24.73 \mathrm{~cm}^{3} \mathrm{~g}-1$ and the PV ranged from 19.5 (TBCM2015-89) to 30.5 (TBCM2015-76) $\mathrm{cm}^{3} \mathrm{~g}-1$ in Antalya site. Experiment average for PV in Çankırı was found $23.39 \mathrm{~cm}^{3} \mathrm{~g}-1$, and it was varied between 12.0 (TBCM201586) and 31.5 (TBCM2015-68) $\mathrm{cm}^{3} \mathrm{~g}-1$. Experiment average was $19.3 \mathrm{~cm}^{3} \mathrm{~g}-1$ in Samsun location and PV varied in that location from11.3 (TBCM2015-72) to 35.2 (TBCM201593) $\mathrm{cm}^{3} \mathrm{~g}-1$ (Supplementary Table 3).

The average UKR of the genotypes was found 6.4\%, and it varied from 2.2 (TBCM201576) to 12.3 (TBCM2015-52) \% in Antalya Location. An experiment average was found 
to be $23.5 \%$ for Çankırı location. UKR was changed between 5.2 (TBCM2015-70) and 44.8 (TBCM2015-65) \% in this location. It was found that experiment average was $20.3 \%$ UKR in Samsun. Values were changed between 3.3 (Baharcin) to 52.3 (TBCM2015-49) $\%$ in this location (Supplementary Table 3 ).

The KS ranged from 72.3 (TBCM2015-71) to 116.3 (TBCM2015-86) number/10g and the average of KS was found 84.8 number/10g in Antalya Location. Values in this location ranged from 48.0 (TBCM2015-100) to 131.7 (TBCM2015-65) number/10g. In Çankırı location experiment average was 72.0 number/10g and values were changed between 56.7 (TBCM2015-71) and 93.6 (TBCM2015-47) number/10g. It was found that experiment average 73.2 number/10g in Samsun (Supplementary Table 3).

\section{Discussion}

According to the mean GY values, Çankırı location was the best, while Antalya was the worst. Location ecological conditions may affect the GY. Especially, unfavorable high temperature during flowering period seemed to be one of the reason for low yield in Antalya location when compared to Çankırı. While mean of checks for GY was 5.20 t ha1 (the highest of them is 5.46 ton ha-1, Nermincin), 17 genotypes (TBCM2015-80, 56, $52,68,46,87,53,81,62,98,93,92,96,73,101,70,60)$ gave higher $G Y$ than 5.46 tha${ }^{1}$ respectively.

GY is one of the most important trait for both producers and consumers. The GY of popcorn usually depends on genotype and growth conditions [10]. Different genotypes had different grain yield in different environments [6], [11]. GY of Antcin-98 and Nermincin hybrids reported to be 3.75 and $4.47 \mathrm{t}$ ha- 1 respectively in a study [12]. It was reported that GY of popcorn hybrids varied from 2.72 to 4.64 t ha-1 in Turkey [13]. [14] Researcher investigated 30 single cross popcorn hybrids and reported that the mean of genotypes were 4.38 tha- 1 for GY, yield ranged from 3.55 to $5.40 \mathrm{t}$ ha-1. A research team investigated grain component of eight popcorn varieties and reported GY of popcorns ranged from 3.73 to 5.38 tha-1 [15]. It was reported GY of popcorns ranged from 4.78 to 7.38 t ha-1 [16]. Our results are generally similar those studies were given. According to the average of PV of genotypes, the highest value was obtained from Antalya location, while lowest result obtained from Samsun. The studies showed that GY and PV is negatively correlated $[1,17-20]$. Yield was found to be the lowest in the Antalya location, but the high PV at the same location confirms the negative relationship. Again, non- 
popped kernels reduce the volume of the PV. The high nonpopped kernel rate $(6.4 \%)$ in the Antalya location might be effective in finding the high PV volume. While mean of checks for PV is $24.57 \mathrm{~cm}^{3} \mathrm{~g}-1$ (the highest of them was $26.90 \mathrm{~cm}^{3} \mathrm{~g}-1$ (Baharcin), 3 genotypes (TBCM2015-41, 76, 93) had higher PV values than $26.90 \mathrm{~cm}^{3} \mathrm{~g}-1$ respectively. In a study carried out with 35 inbred popcorn lines, mean of the genotypes for PV determined as $19.49 \mathrm{~cm}^{3} \mathrm{~g}-1$ [21]. The researchers reported that there was an important positive correlation between PV and kernel size, and negative correlation between PV and UKR. It was reported that PV changed from $19.79 \mathrm{~cm}^{3} \mathrm{~g}-1$ to $22.92 \mathrm{~cm}^{3} \mathrm{~g}-1$ in another study [22]. Our results seem to be higher than other reports. Hybrids potential for these traits probably increased the values in our study. It was reported that the means of PV was $42.00 \mathrm{~cm}^{3} \mathrm{~g}-1$ and changed from $38.20 \mathrm{~cm}^{3} \mathrm{~g}-1$ to $46.50 \mathrm{~cm}^{3} \mathrm{~g}-1$ [14]. In another study PV changed from $28.00 \mathrm{~cm}^{3} \mathrm{~g}-1$ to $40.17 \mathrm{~cm}^{3} \mathrm{~g}-1$ [16]. Our results in terms of these traits were lower than mentioned studies. It is thought that both environment and genotypes affected the different results.

UKR is one of the most important quality parameter and significantly affects the PV. Popcorn consumers prefer high PV, delicious, low gumminess, and low unpopped kernel. Also crop breeders have been striving to develop genotypes with superior grain yield, quality and other desirable characteristics over a wide range of different environmental conditions. As a result of this research, it was determined that genotypes TBCM2015$76,78,53,75$ and, 70 are promising as low $12 \%$ according to UKR.

$\mathrm{KS}$ is another important quality trait and affects indirectly PV UKR [23]. Home consumers generally prefer small kernel types. Vendors usually prefer larger kernel, while medium kernels preferred by both home users and vendors [5].

Four of the hybrids studied in this research, (TBCM2015-100, 71, 46 and Antcin98) were in the small class (52-67 number/10g), 16 of them (TBCM2015-48, Elacin, 99, 83, 82, 98, 44, 60, SH9201, 53, 92, 87, 64, 96, 45 and 103) were in the medium class (68-75 number/10g) and 29 of them (TBCM2015-80, Baharcin, 70, 84, 49, 77, 56, 52, 68, 81, $97,62,43,72,61$, Nermincin, 55, 101, 75, 73, 76, 78, 93, 47, 86, 65 and 67) were in the large class (78-105 number/10g). It was suggested that larger-sized grains produced greater flake size than small-medium sized grain [24].

In this research genotype $\mathrm{x}$ environment interaction (GEI) was statistically significant at $P<0.01$. Likewise [25] reported that there was a significant GEI in popcorn hybrids 
evaluated in different locations of Turkey. In maize breeding, the effects of Genotype $\mathrm{x}$ Environment interaction on the stability and adaptability are very important because of the fact that every cultivar has a connatural capacity to respond to the changes of environment [26]. But especially in popcorn, the correlations between the stability and adaptability statistics are not yet well understood, and selection of genotype based on the average crop yield is ineffective [27]. There are many methods to determine stability analysis. In the regression methods, it is assumed that performance of genotypes will may increase in good environmental. Hence, it is important to know not only average performance of genotypes but also magnitude of the genotype $\mathrm{x}$ environment interaction in the selection. [25].

The researchers proposed a model to test the stability of varieties under various environments [28]. They defined a stable variety as having unit regression over the environments $(b=1.00)$ and minimum deviation from the regression $(\mathrm{S} 2 \mathrm{di}=0)$.

Therefore, a variety with a high mean yield over the environments, unit regression coefficient $(b=1)$ and deviation from regression as small as possible (S2d=0), will be a better choice as a stable variety. The average results of both grain yield and PV and stability analyze of popcorn genotypes investigated three locations were given in Table 4, the diagrammatic presentation of GY and PV were given figure 1, 2 respectively.

Table 4 The stability parameters for both GY and PV in popcorn genotypes in three different environments

\begin{tabular}{|c|c|c|c|c|c|c|c|c|c|c|c|c|}
\hline & \multicolumn{6}{|c|}{ Grain Yield (GY) } & \multicolumn{6}{|c|}{ Popping Volume (PV) } \\
\hline & $\bar{X}$ & $\mathrm{~b}$ & $\mathrm{a}$ & VK & $\mathrm{r} 2$ & $\mathrm{~S}^{2} \mathrm{~d}$ & $\mathrm{X}$ & $\mathrm{b}$ & $\mathrm{a}$ & VK & r2 & $\mathrm{S}^{2} \mathrm{~d}$ \\
\hline $2015-41$ & 514.83 & 1.7 & -391 & 0.06 & 0.94 & 3957.5 & 29.93 & -0.83 & 48.65 & 0.01 & 1 & 0.05 \\
\hline $2015-43$ & 447.96 & 1.51 & -356.6 & 0 & 1 & 3.41 & 23.23 & 1.67 & -14.43 & 0.14 & 0.75 & 15.13 \\
\hline $2015-44$ & 525.85 & 0.49 & 263.02 & 0.08 & 0.47 & 5563.4 & 19.3 & 1.5 & -14.49 & 0.14 & 0.71 & 14.27 \\
\hline $2015-45$ & 519.94 & 1.05 & -41.71 & 0.11 & 0.65 & 12289 & 21.73 & 2.27 & -29.27 & 0.23 & 0.68 & 38.88 \\
\hline $2015-46$ & 599.79 & 0.73 & 211.9 & 0.04 & 0.86 & 1707.7 & 21.93 & 0.88 & 2.05 & 0.14 & 0.45 & 14.98 \\
\hline $2015-47$ & 412.09 & 1.52 & -400.7 & 0.02 & 0.99 & 513.51 & 19.77 & 0.3 & 13.01 & 0.11 & 0.14 & 8.9 \\
\hline $2015-48$ & 518.44 & 0.46 & 272.57 & 0.11 & 0.27 & 11675 & 24.43 & 2.55 & -32.81 & 0.06 & 0.98 & 2.58 \\
\hline 2015-49 & 531.38 & 0.44 & 295.54 & 0.02 & 0.94 & 243.62 & 22.53 & 3.1 & -47.26 & 0.23 & 0.79 & 41.56 \\
\hline $2015-52$ & 613.88 & 0.34 & 434.7 & 0.07 & 0.33 & 4615.7 & 22.33 & 2.55 & -34.94 & 0.17 & 0.82 & 21.78 \\
\hline $2015-53$ & 590.37 & 0.58 & 281.75 & 0.11 & 0.38 & 11299 & 25.43 & 0.41 & 16.23 & 0.14 & 0.15 & 14.6 \\
\hline $2015-55$ & 503.49 & 1.17 & -121.4 & 0.01 & 0.99 & 206.43 & 21.93 & 1.08 & -2.31 & 0.29 & 0.23 & 62.33 \\
\hline
\end{tabular}




\begin{tabular}{|c|c|c|c|c|c|c|c|c|c|c|c|c|}
\hline $2015-56$ & 638.88 & -0.31 & 801.68 & 0.01 & 0.97 & 51.68 & 20.57 & 2.26 & -30.24 & 0.01 & 1 & 0.07 \\
\hline $2015-60$ & 547.73 & 0.49 & 285.9 & 0 & 1 & 3.53 & 20.2 & 2.24 & -30.2 & 0.12 & 0.88 & 10.74 \\
\hline $2015-61$ & 466.53 & 0.72 & 82.73 & 0.2 & 0.22 & 37265 & 20.6 & 2.03 & -24.99 & 0.1 & 0.9 & 6.92 \\
\hline $2015-62$ & 580.67 & -0.07 & 617.18 & 0.05 & 0.03 & 2692.6 & 20.6 & 3.01 & -47.05 & 0.05 & 0.99 & 2.06 \\
\hline 2015-64 & 486.1 & 1.36 & -240.9 & 0.05 & 0.93 & 2847.2 & 20 & 2.07 & -26.53 & 0.03 & 0.99 & 0.86 \\
\hline $2015-65$ & 540.76 & 1.58 & -303.5 & 0.01 & 1 & 152.63 & 20.13 & 0.95 & -1.13 & 0.05 & 0.9 & 1.59 \\
\hline $2015-67$ & 453.95 & 0.91 & -29.82 & 0.08 & 0.73 & 6174.6 & 21.07 & 0.92 & 0.43 & 0.01 & 0.99 & 0.15 \\
\hline $2015-68$ & 613.16 & 0.49 & 349.59 & 0.01 & 0.99 & 74.36 & 23.9 & 2.29 & -27.51 & 0.26 & 0.62 & 51.54 \\
\hline $2015-70$ & 552.12 & 0.28 & 404.44 & 0.01 & 0.96 & 61.44 & 23.87 & 0.52 & 12.08 & 0 & 1 & 0.01 \\
\hline $2015-71$ & 529.03 & 0.84 & 81.37 & 0.05 & 0.84 & 2757.2 & 23.03 & 0.53 & 11.02 & 0.12 & 0.29 & 11.14 \\
\hline $2015-72$ & 531.57 & 1.29 & -156 & 0.04 & 0.96 & 1487.2 & 19.03 & 2.44 & -35.88 & 0.01 & 1 & 0.04 \\
\hline $2015-73$ & 563.66 & 1.5 & -235.6 & 0.02 & 0.99 & 315.13 & 23.3 & 2.48 & -32.49 & 0.13 & 0.89 & 12.32 \\
\hline $2015-75$ & 481.1 & 1.16 & -137.1 & 0 & 1 & 3.57 & 22.37 & 1.99 & -22.46 & 0.1 & 0.9 & 6.99 \\
\hline $2015-76$ & 545.04 & 1.35 & -173.4 & 0.07 & 0.9 & 4200.9 & 27.43 & -0.22 & 32.37 & 0.22 & 0.02 & 36.47 \\
\hline $2015-77$ & 530.86 & 0.57 & 227.49 & 0.04 & 0.83 & 1313.7 & 25.47 & 0.21 & 20.85 & 0.18 & 0.03 & 25.42 \\
\hline $2015-78$ & 514.75 & 1.75 & -416.3 & 0 & 1 & 13.01 & 22.07 & 1.74 & -17.04 & 0.05 & 0.96 & 2.18 \\
\hline $2015-80$ & 692.31 & 0.59 & 378.1 & 0.01 & 0.98 & 124.28 & 20.63 & 1.94 & -22.99 & 0.17 & 0.73 & 22.38 \\
\hline $2015-81$ & 587.72 & 1.36 & -140.5 & 0.05 & 0.94 & 2491 & 23.7 & -1.5 & 57.53 & 0.03 & 0.99 & 0.52 \\
\hline $2015-82$ & 481.49 & 1.29 & -208.4 & 0.05 & 0.92 & 2794.5 & 20.6 & 2.2 & -28.83 & 0.09 & 0.93 & 5.92 \\
\hline $2015-83$ & 543.84 & 0.07 & 508.85 & 0.09 & 0.01 & 7614.3 & 21.77 & 2.15 & -26.55 & 0.02 & 1 & 0.24 \\
\hline $2015-84$ & 528.51 & 0.35 & 341.75 & 0.09 & 0.22 & 8666 & 22.63 & 1.22 & -4.8 & 0.04 & 0.96 & 0.94 \\
\hline $2015-86$ & 423.83 & 2.05 & -671.5 & 0.07 & 0.94 & 5072.7 & 16.03 & 1.21 & -11.13 & 0.24 & 0.35 & 42.78 \\
\hline $2015-87$ & 593.15 & 0.47 & 342.8 & 0.12 & 0.25 & 13574 & 23.17 & 2.04 & -22.66 & 0.05 & 0.98 & 1.58 \\
\hline $2015-92$ & 570.12 & -0.06 & 600.5 & 0.03 & 0.06 & 1128.3 & 18.83 & 0.48 & 8.04 & 0.31 & 0.05 & 74.53 \\
\hline 2015-93 & 572.1 & 0.87 & 106.68 & 0.13 & 0.48 & 16472 & 26.97 & -2.55 & 84.2 & 0.04 & 0.99 & 1.2 \\
\hline $2015-95$ & 519.75 & 1.09 & -63.01 & 0.14 & 0.57 & 18445 & 19.1 & 2.1 & -28.02 & 0.06 & 0.97 & 2.35 \\
\hline 2015-96 & 568.9 & 1.04 & 12.81 & 0.08 & 0.78 & 6164.5 & 20.53 & -1.78 & 60.49 & 0.31 & 0.4 & 73.54 \\
\hline $2015-97$ & 530.23 & 0.98 & 9.67 & 0.05 & 0.9 & 2046.5 & 22.33 & -0.37 & 30.56 & 0.28 & 0.03 & 60.57 \\
\hline $2015-98$ & 574.53 & 1.29 & -113.6 & 0.1 & 0.79 & 9108.6 & 23.37 & 0.06 & 21.93 & 0.09 & 0.01 & 5.72 \\
\hline 2015-99 & 459.45 & 1.66 & -425.4 & 0.12 & 0.79 & 15049 & 22.27 & -0.86 & 41.6 & 0.05 & 0.85 & 2.01 \\
\hline $2015-100$ & 440.36 & 1.69 & -461.3 & 0.01 & 1 & 43.49 & 25.77 & 0.6 & 12.37 & 0.2 & 0.15 & 31.41 \\
\hline 2015-101 & 561.46 & 1.79 & -394.9 & 0.08 & 0.9 & 6869.6 & 19.7 & 1.15 & -6.07 & 0.04 & 0.96 & 0.94 \\
\hline 2015-103 & 540.76 & 0.77 & 129.24 & 0.01 & 0.99 & 105.55 & 25.43 & -0.75 & 42.28 & 0.19 & 0.25 & 26.74 \\
\hline Antcin-98 & 542.66 & 1.71 & -371 & 0 & 1 & 1.34 & 23.6 & 1.38 & -7.4 & 0.16 & 0.61 & 19.37 \\
\hline Baharcin & 530.66 & 1.78 & -419.1 & 0.06 & 0.95 & 3463.4 & 26.9 & -1.79 & 67.15 & 0.24 & 0.55 & 41.95 \\
\hline
\end{tabular}




\begin{tabular}{|c|c|c|c|c|c|c|c|c|c|c|c|c|}
\hline Elacin & 542.99 & 1.63 & -324.2 & 0 & 1 & 17.53 & 26.1 & -1.65 & 63.24 & 0.13 & 0.77 & 12.79 \\
\hline Nermincin & 545.68 & 1.07 & -24.39 & 0.03 & 0.97 & 720.31 & 21.2 & 2.24 & -29.24 & 0.23 & 0.66 & 40.15 \\
\hline Sh9201 & 437.87 & 1.61 & -419.1 & 0.06 & 0.94 & 3274.4 & 25.07 & 0.55 & 12.66 & 0.14 & 0.26 & 14 \\
\hline Confidence interval & ${ }^{-} \mathrm{x}= \pm 18.0$ & & & & & & $-\mathrm{x}= \pm 0.1$ & & & & & \\
\hline
\end{tabular}

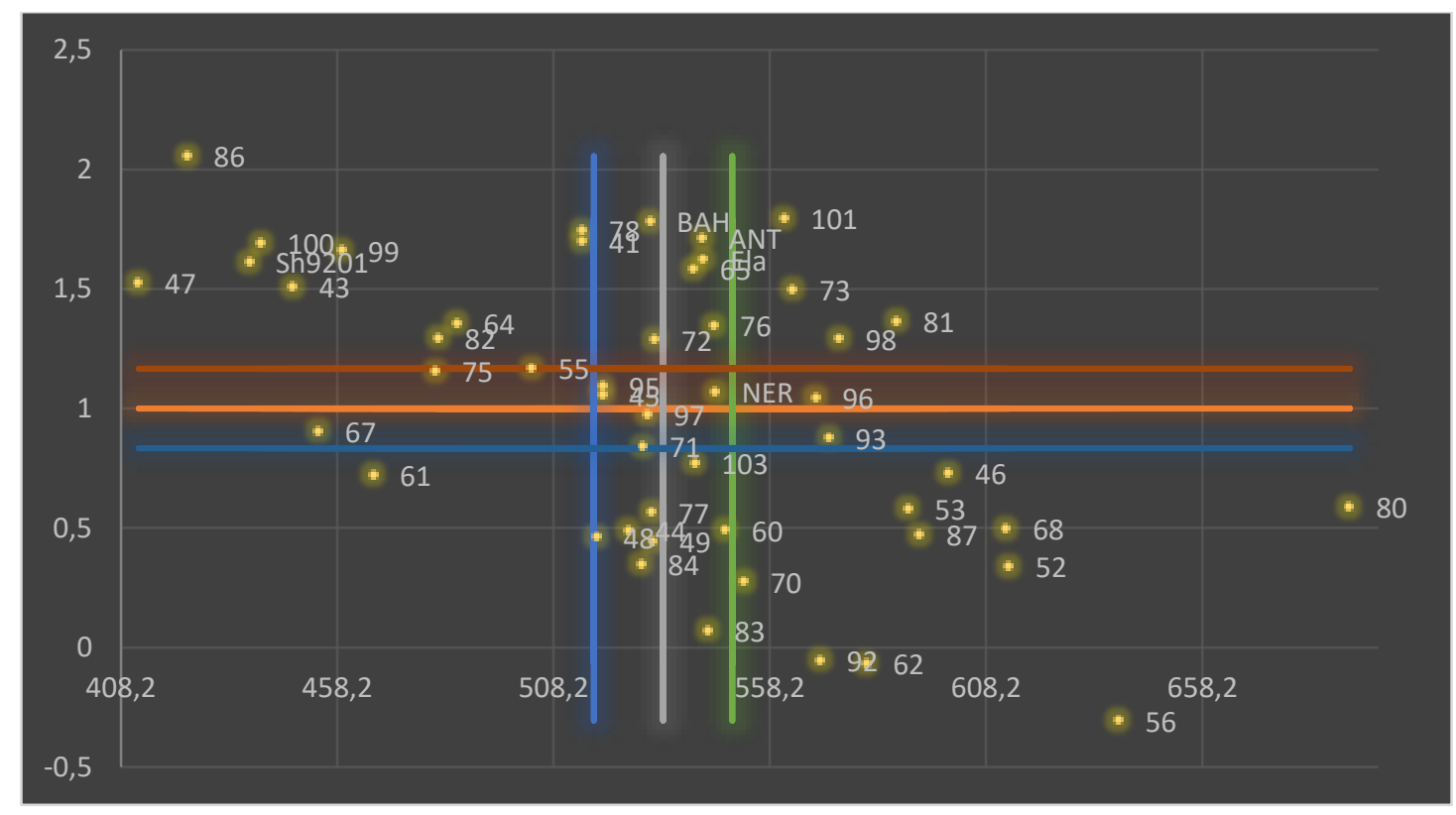

Fig 1 Scattered diagram for GY of popcorn genotypes in three locations 


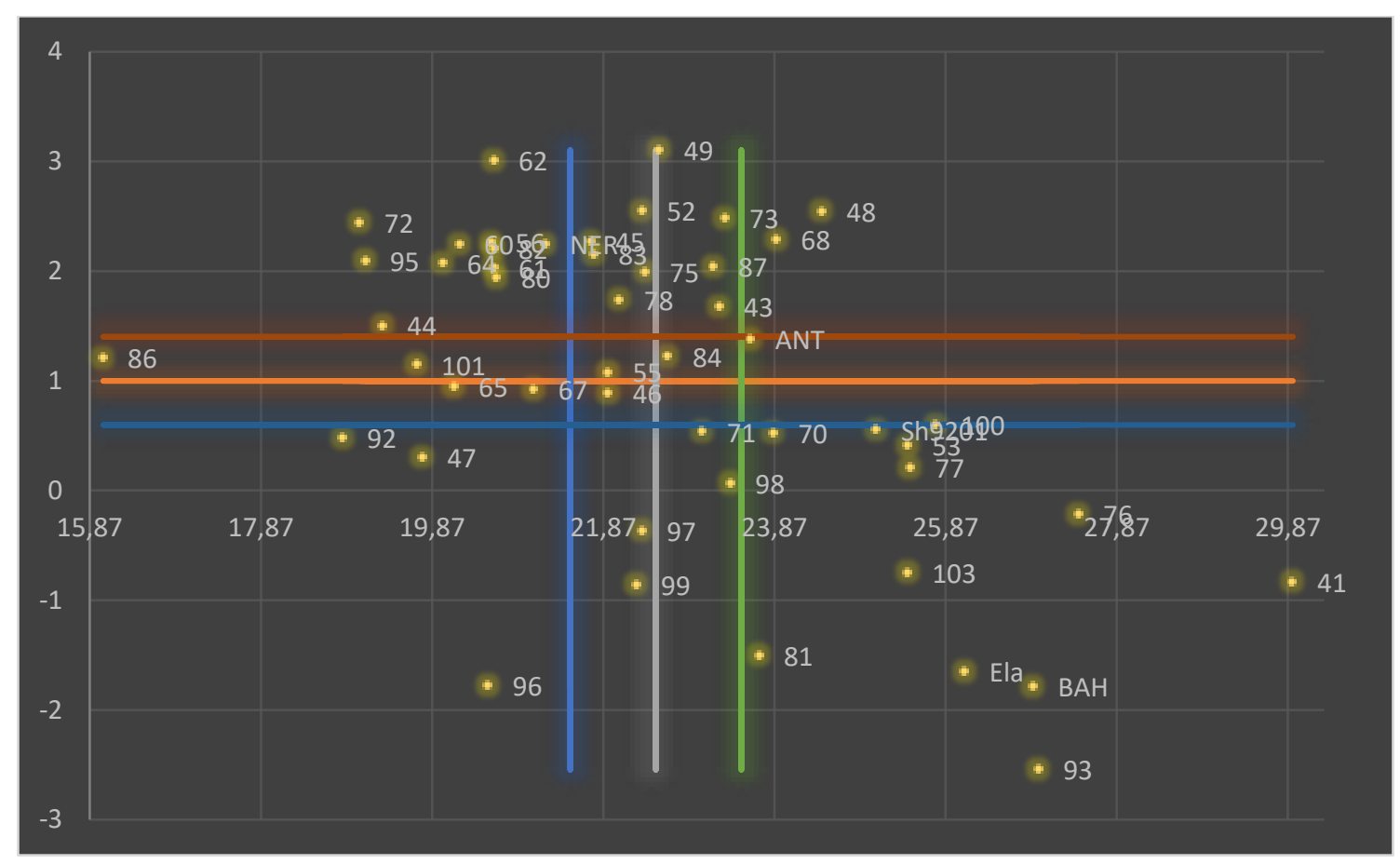

Fig 2 Scattered diagram for PV of popcorn genotypes in three locations

The GY of experimental varied between 4.12 and $6.92 \mathrm{t}$ ha-1. The highest GY of experimental mean was found in TBCM2015-80, TBCM2015-56 and TBCM2015-52 respectively. While the highest of checks for GY is $5.46 \mathrm{t}$ ha-1 (Nermincin), the 30 genotypes gave higher GY than Nermincin (Supplementary Table 3). TBCM2015$43,60,75,78$ and 100 genotypes are thought as the most stabile genotypes due to b and R2 values of them are closed 1 and 0. TBCM2015-52, 56 and 52 genotypes giving the highest GY in research have shown good adapt in good environmental condition about GY. According to researchers [28], TTM2015-56, 87 and 95 genotypes are thought as the most stabile genotypes due to $\mathrm{b}$ and $\mathrm{R} 2$ values of them are closed 1 and 0 respectively.

\section{Conclusion}

As a result of the research, TBCM2015-41, 56, 62, 76, 80 and 93 popcorn hybrids selected for their high yield and quality characteristics. These popcorn hybrids are promising and could be used to meet both producer and consumer demands in the future.

\section{Acknowledgements}

This research was supported by the Scientific and Technological Research Council of Turkey (TUBITAK) with project no: 2140003 . The authors thank to TUBITAK for funding and supporting. 


\section{References}

1. Pajić, Z. and M. Babić, Interrelation of popping volume and some agronomic characteristics in popcorn hybrids. 1991.

2. Nguyen, V., et al., Popcorn is more satiating than potato chips in normal-weight adults. Nutrition Journal, 2012. 11(1): p. 71.

3. Pajić, Z., Breeding of maize types with specific traits at the Maize Research Institute, Zemun Polje. Genetica, 2007. 39(2): p. 169-180.

4. Dolijanovic, J., et al., The effects of different cover crops on grain yield of popcorn (zea mays 1. Ssp. Everta sturt). Annals of the University of Craiova-Agriculture, Montanology, Cadastre Series, 2017. 46(1): p. 129-133.

5. Ziegler, K.E., et al., Popcorn production and marketing. 1984: Oklahoma State University. p. 2014 1 - 2014-7.

6. Öz, A. and H. Kapar, Determination of Grain Yield, Some Yield and Quality Traits of Promising Hybrid Popcorn Genotypes. Turkish Hournal of Field Crops, 2011. 16(2): p. 233-238.

7. Öztürk, A., et al., Utilization and Future of Special Corn Types in Turkey, in International Conferance on Agriculture, Forest, Food Sciences and Techonologies 2017, 1: Nevsehir / TURKEY. p. 820.

8. Ertaş, N., S. Soylu, and N. Bilgiçli, Mısırın fiziksel özellikleri ile patlama kalitesi arasındaki ilişkilerin belirlenmesi üzerine bir araştırma Türkiye 10. Gıda Kongresi, 2008: p. 21-23.

9. Dofing, S., M. Thomas-Compton, and J. Buck, GenotypeX Popping Method Interaction for Expansion Volume in Popcorn. Crop Science, 1990. 30(1): p. 62-65.

10. Tekkanat, A. and S. Soylu, Cin Mısır Çeşitlerinin Tane Verimi Ve Önemli Kalite Özelliklerinin Belirlenmesi. Selçuk Tarım Bilimleri Dergisi, 2005. 19(37): p. 51-60.

11. Özkan, A. and A.C. Ülger, Çukurova Ekolojik Koşullarında Değişik Azot Dozu Uygulamalarının İki Cin Mısırı (Zea mays L. everta Sturt.) Çeşidinde Tane Verimi ve Bazı Tarımsal Özelliklere Etkisi. Yüzüncü Yıl Üniversitesi Tarım Bilimleri Dergisi, 2011. 21(3): p. 198-208.

12. Sakin, M.A., et al., Effects of cultivar type on yield and quality of popcorn (Zea mays everta). New Zealand journal of crop and horticultural science, 2005. 33(1): p. 17-23.

13. Özkaynak, E. and B. Samancı, Cin mısır (Zea mays everta Sturt.) hatlarının ve yoklama melezlerinin verim ve verimle ilgili özellikler bakımından karşılaştırılması. Akdeniz Üniversitesi Ziraat Fakültesi Dergisi, 2003. 16(1): p. 35-42.

14. Öz, A. and H. Kapar, Determination of grain yield, some yield and quality traits of promising hybrid popcorn genotypes. Turkish Journal of Field Crops, 2011. 16(2): p. 233-238.

15. Ozata, E., S.U. Ikincikarakaya, and A. Ozturk, Correlation and path coefficient analysis for some ear yield related traits in popcorn (zea mays var. Everta). International Scientific, 2018: p. 169.

16. Srdić, J., et al., Evaluation of agronomic and sensory characteristics of the popcorn kernel. Journal on Processing and Energy in Agriculture, 2017. 21(4): p. 185-187.

17. Song, A., et al., Effects of kernel size and genotype on popcorn popping volume and number of unpopped kernels. Cereal chemistry, 1991.

18. Ceylan, M. and E. Karababa, Comparison of sensory properties of popcorn from various types and sizes of kernel. Journal of the Science of Food and Agriculture, 2002. 82(1): p. 127-133.

19. Özkan, A. and A. Ülger, Çukurova koşullarında değişik azot dozu uygulamalarının iki cin mısırı (Zea mays everta Sturt.) çeşidinde tane verimi, tarımsal özellikler ve bazı kalite özelliklerine etkisi. Doktora Tezi, Çukurova Üniversitesi (Basılmamış), Adana, 2007.

20. Broccoli, A. and R. Burak, Association between yield components, grain morphological traits and volume expansion in popcorn hybrids cultivated in Argentina. Maize Genetics Cooperation Newsletter, 2000 (74): p. 43-44.

21. Öztürk, A., et al., Cin mısır hatlarının bazı kalite özellikleri ve özellikler arası ilişkilerin belirlenmesi. Derim, 2016. 33(1): p. 119-130. 
22. Ertaş, N., S. Soylu, and N. Bilgiçli, Mısırın Fiziksel Özellikleri ile Patlama Kalitesi Arasındaki İlişkilerin Belirlenmesi Üzerine Bir Araştırma, in Türkiye 10. Gıda Kongresi. 2008: Erzurum. p. 21-23.

23. Sweley, J.C., D.J. Rose, and D.S. Jackson, Quality traits and popping performance considerations for popcorn (Zea mays Everta). Food reviews international, 2013. 29(2): p. 157- 177.

24. Gökmen, S., Effects of moisture content and popping method on popping characteristics of popcorn. Journal of Food Engineering, 2004. 65(3): p. 357-362.

25. Erdal, S., et al., Additive main effects and multiplicative interactions analysis of yield in popcorn (Zea mays everta L.) hybrids. Akdeniz Üniversitesi Ziraat Fakültesi Dergisi, 2012. 25(2): p. 117121.

26. Scapim, C.A., et al., Correlations between the stability and adaptability statistics of popcorn cultivars. Euphytica, 2010. 174(2): p. 209-218.

27. Hopkins, A.A., et al., Genotype Effects and Genotype by Environment Interactions for Traits of Elite Switchgrass Populations. 1995.

28. Eberhart, S. and W. Russell, Stability parameters for comparing varieties 1. Crop Science, 1966. 6(1): p. 36-40. 
Supplementary Table 3 Mean grain yield (t ha -1), popping volume $\left(\mathrm{cm}^{3} \mathrm{~g}-1\right)$, unpopped kernel ratio (\%) and kernel size (number/10g) obtained from popcorn hybrids across locations

\begin{tabular}{|c|c|c|c|c|c|c|c|c|c|c|c|c|c|}
\hline & \multirow[t]{2}{*}{ Genotype } & \multicolumn{3}{|c|}{ Grain Yield (GY) } & \multicolumn{3}{|c|}{ Popping volume (PV) } & \multicolumn{3}{|c|}{ Unpopped kernel (UKR) } & \multicolumn{3}{|c|}{ Kernel Size (KS) } \\
\hline & & Antalya & Çankırı & Samsun & Antalya & Çankırı & Samsun & Antalya & Çankırı & Samsun & Antalya & Çankırı & Samsun \\
\hline 1 & $2015-41$ & 3.14 & 5.85 & 6.46 & 28.2 & 29 & 32.6 & 8.4 & 11.3 & 36.9 & 92.3 & 71.7 & 67.7 \\
\hline 2 & $2015-43$ & 2.73 & 5.47 & 5.24 & 24.7 & 27.8 & 17.2 & 6.1 & 23.8 & 30.0 & 95.7 & 65.7 & 74.3 \\
\hline 3 & $2015-44$ & 4.64 & 5.08 & 6.05 & 24.9 & 17.7 & 15.3 & 5.4 & 26.1 & 30.9 & 76.3 & 63.3 & 73.3 \\
\hline 4 & $2015-45$ & 3.90 & 5.15 & 6.54 & 30.5 & 18.9 & 15.8 & 4.1 & 40.7 & 33.2 & 87.7 & 72.0 & 64.3 \\
\hline 5 & $2015-46$ & 5.18 & 6.76 & 6.05 & 26.2 & 19.7 & 19.9 & 7.3 & 28.6 & 17.1 & 73.0 & 56.3 & 69.3 \\
\hline 6 & $2015-47$ & 2.34 & 4.98 & 5.05 & 22.2 & 17.7 & 19.4 & 6.1 & 39.4 & 9.7 & 91.0 & 72.0 & 96.3 \\
\hline 7 & $2015-48$ & 4.72 & 6.21 & 4.62 & 29.2 & 28 & 16.1 & 9.5 & 14.7 & 12.0 & 75.0 & 64.3 & 65.3 \\
\hline 8 & $2015-49$ & 4.79 & 5.50 & 5.65 & 25.7 & 30.4 & 11.5 & 11.8 & 17.4 & 52.3 & 83.7 & 79.3 & 65.0 \\
\hline 9 & $2015-52$ & 5.79 & 6.82 & 5.80 & 25.3 & 28.3 & 13.4 & 12.3 & 11.6 & 18.7 & 74.7 & 79.7 & 77.3 \\
\hline 10 & $2015-53$ & 5.30 & 7.00 & 5.41 & 24.1 & 28.8 & 23.4 & 5.4 & 11.4 & 16.2 & 79.0 & 60.7 & 77.3 \\
\hline 11 & $2015-55$ & 3.67 & 5.71 & 5.72 & 19.7 & 29.1 & 17.0 & 7.5 & 18.8 & 16.2 & 81.7 & 82.0 & 79.7 \\
\hline 12 & $2015-56$ & 6.75 & 6.24 & 6.18 & 25.8 & 22.4 & 13.5 & 4.3 & 22.1 & 18.5 & 84.3 & 70.0 & 76.7 \\
\hline 13 & $2015-60$ & 4.91 & 5.79 & 5.74 & 23.3 & 24.8 & 12.5 & 3.2 & 15.2 & 19.9 & 82.3 & 73.7 & 57.3 \\
\hline 14 & 2015-61 & 3.70 & 3.85 & 6.45 & 23.6 & 24.5 & 13.7 & 6.2 & 24.4 & 34.8 & 89.0 & 87.0 & 60.7 \\
\hline 15 & 2015-62 & 5.92 & 6.11 & 5.39 & 28.2 & 22.2 & 11.4 & 9.2 & 25.5 & 16.9 & 90.7 & 68.0 & 75.7 \\
\hline 16 & 2015-64 & 3.25 & 5.40 & 5.93 & 24.1 & 22.6 & 13.3 & 10.4 & 14.5 & 33.2 & 78.7 & 71.3 & 69.7 \\
\hline 17 & 2015-65 & 3.58 & 6.54 & 6.10 & 23 & 20 & 17.4 & 6.8 & 44.8 & 16.4 & 85.0 & 131.7 & 68.0 \\
\hline 18 & $2015-67$ & 3.44 & 4.61 & 5.57 & 22.9 & 22.2 & 18.1 & 4.0 & 40.5 & 12.9 & 95.3 & 125.0 & 94.7 \\
\hline 19 & 2015-68 & 5.55 & 6.40 & 6.44 & 24.8 & 31.6 & 15.3 & 6.0 & 37.1 & 18.2 & 84.7 & 70.0 & 79.0 \\
\hline 20 & $2015-70$ & 5.20 & 5.65 & 5.72 & 25 & 24.4 & 22.2 & 11.4 & 5.2 & 18.6 & 83.0 & 81.0 & 62.7 \\
\hline
\end{tabular}




\begin{tabular}{|c|c|c|c|c|c|c|c|c|c|c|c|c|c|}
\hline 21 & $2015-71$ & 4.28 & 5.49 & 6.10 & 26.2 & 20.9 & 22.0 & 10.5 & 30.5 & 29.8 & 72.3 & 69.7 & 56.7 \\
\hline 22 & $2015-72$ & 3.85 & 6.43 & 5.67 & 24.4 & 21.4 & 11.3 & 7.0 & 20.0 & 43.7 & 90.3 & 81.3 & 64.3 \\
\hline 23 & $2015-73$ & 3.89 & 6.51 & 6.51 & 26.8 & 28.3 & 14.8 & 4.4 & 18.0 & 16.2 & 88.0 & 75.0 & 89.7 \\
\hline 24 & $2015-75$ & 3.47 & 5.59 & 5.37 & 28.4 & 22.1 & 16.6 & 4.8 & 21.6 & 8.8 & 88.7 & 72.3 & 90.7 \\
\hline 25 & $2015-76$ & 3.85 & 5.91 & 6.60 & 30.5 & 22.5 & 29.3 & 2.2 & 17.7 & 9.2 & 92.0 & 74.0 & 87.7 \\
\hline 26 & 2015-77 & 4.63 & 5.44 & 5.86 & 28.9 & 21.7 & 25.8 & 9.6 & 25.6 & 9.7 & 78.7 & 71.3 & 79.3 \\
\hline 27 & $2015-78$ & 3.13 & 6.33 & 5.99 & 25.1 & 24.8 & 16.3 & 6.5 & 18.2 & 7.5 & 89.0 & 75.0 & 91.0 \\
\hline 28 & $2015-80$ & 6.25 & 7.39 & 7.13 & 22.2 & 26.1 & 13.6 & 6.2 & 28.2 & 21.2 & 86.3 & 56.7 & 82.3 \\
\hline 29 & $2015-81$ & 4.26 & 6.45 & 6.92 & 19.9 & 22.9 & 28.3 & 7.7 & 17.3 & 16.3 & 85.3 & 78.0 & 70.7 \\
\hline 30 & $2015-82$ & 3.35 & 6.03 & 5.07 & 24.1 & 24.5 & 13.2 & 3.0 & 10.2 & 30.7 & 85.0 & 66.3 & 59.0 \\
\hline 31 & $2015-83$ & 5.30 & 4.90 & 6.12 & 26.3 & 24.1 & 14.9 & 3.6 & 21.1 & 34.2 & 82.7 & 65.3 & 61.7 \\
\hline 32 & $2015-84$ & 4.82 & 4.89 & 6.15 & 24.8 & 24.5 & 18.6 & 8.8 & 16.8 & 21.3 & 92.7 & 66.3 & 68.7 \\
\hline 33 & $2015-86$ & 1.90 & 6.08 & 4.73 & 22.6 & 12 & 13.5 & 7.4 & 43.8 & 28.8 & 116.3 & 70.7 & 75.3 \\
\hline 34 & $2015-87$ & 5.46 & 7.02 & 5.31 & 27 & 26 & 16.5 & 2.3 & 24.7 & 12.1 & 77.7 & 60.0 & 80.3 \\
\hline 35 & $2015-92$ & 5.74 & 5.44 & 5.92 & 25 & 12.5 & 19.0 & 7.3 & 24.1 & 12.3 & 79.7 & 61.7 & 76.0 \\
\hline 36 & $2015-93$ & 4.79 & 7.16 & 5.21 & 21.9 & 23.8 & 35.2 & 2.3 & 25.2 & 9.0 & 91.7 & 74.0 & 89.7 \\
\hline 37 & 2015-95 & 3.84 & 5.01 & 6.74 & 22.9 & 22.2 & 12.2 & 3.0 & 21.8 & 14.7 & 81.7 & 64.0 & 82.3 \\
\hline 38 & $2015-96$ & 4.53 & 6.91 & 5.63 & 21.6 & 12.2 & 27.8 & 6.9 & 36.7 & 7.9 & 84.0 & 61.7 & 77.3 \\
\hline 39 & $2015-97$ & 4.20 & 6.25 & 5.45 & 26.1 & 15.9 & 25 & 2.2 & 30.8 & 6.6 & 85.0 & 65.7 & 83.3 \\
\hline 40 & 2015-98 & 4.31 & 7.24 & 5.68 & 22.1 & 25.3 & 22.7 & 3.0 & 23.2 & 27.6 & 83.7 & 64.7 & 63.0 \\
\hline
\end{tabular}




\begin{tabular}{|c|c|c|c|c|c|c|c|c|c|c|c|c|c|}
\hline 41 & $2015-99$ & 2.75 & 6.52 & 4.51 & 19.5 & 22.6 & 24.7 & 6.5 & 17.4 & 18.8 & 80.7 & 67.7 & 60.3 \\
\hline 42 & $2015-100$ & 2.45 & 5.57 & 5.20 & 23.8 & 30.7 & 22.8 & 7.6 & 20.4 & 20.9 & 80.3 & 48.0 & 57.3 \\
\hline 43 & $2015-101$ & 3.59 & 7.36 & 5.90 & 21.7 & 21.5 & 15.9 & 5.1 & 9.5 & 25.8 & 91.7 & 90.7 & 69.0 \\
\hline 44 & $2015-103$ & 4.51 & 5.85 & 5.87 & 26.8 & 20.7 & 28.8 & 6.4 & 17.2 & 30.4 & 85.3 & 80.3 & 59.3 \\
\hline 45 & Antcin-98 & 3.44 & 6.57 & 6.27 & 24.1 & 28.3 & 18.4 & 6.7 & 21.5 & 38.2 & 80.7 & 60.0 & 59.7 \\
\hline 46 & Baharcin & 3.20 & 6.09 & 6.63 & 26.7 & 20.2 & 33.8 & 8.7 & 37.7 & 3.3 & 73.3 & 67.7 & 84.7 \\
\hline 47 & Elacin & 3.55 & 6.53 & 6.21 & 24.5 & 21.8 & 32 & 6.6 & 28.3 & 4.7 & 78.7 & 55.7 & 74.0 \\
\hline 48 & Nerminci & 4.20 & 5.98 & 6.19 & 22.5 & 28.2 & 12.9 & 5.1 & 37.4 & 7.0 & 88.7 & 70.7 & 79.3 \\
\hline 49 & Sh9201 & 2.55 & 5.83 & 4.76 & 24.1 & 28.5 & 22.6 & 5.4 & 13.2 & 14.8 & 83.7 & 68.7 & 61.3 \\
\hline \multicolumn{2}{|c|}{ Standards Mean } & 3.39 & 6.20 & 6.01 & 24 & 25 & 24 & 6 & 27.6 & 13.6 & 81.0 & 64.5 & 71.8 \\
\hline \multicolumn{2}{|c|}{ Genotypes Mean } & 4.26 & 5.97 & 5.81 & 25 & 23 & 19 & 6 & 23.0 & 21.0 & 85.3 & 72.8 & 73.4 \\
\hline \multicolumn{2}{|c|}{ Experiment Mean } & $4.18 \mathrm{c}$ & $6.00 \mathrm{a}$ & $5.83 \mathrm{~b}$ & $25 a$ & $23 b$ & $19 \mathrm{c}$ & 6 & 23.5 & 20.3 & 84.8 & 72.0 & 73.2 \\
\hline \multicolumn{2}{|c|}{ CV (\%) } & 13.2 & 11.7 & 10.8 & 1.06 & 1.07 & 1.67 & 13.08 & 8.58 & 10.46 & 2.54 & 2.93 & 2.74 \\
\hline \multicolumn{2}{|c|}{ LSD } & 1.02 & 1.29 & 1.62 & 0.48 & 0.46 & 3.89 & 1.55 & 3.75 & 3.68 & 3.95 & 3.93 & 3.68 \\
\hline \multicolumn{2}{|l|}{$\mathbf{F}$} & $<.0001$ & $<.0001$ & $<.0001$ & $<.0001$ & $<.0001$ & $<.0001$ & $<.0001$ & $<.0001$ & $<.0001$ & $<.0001$ & $<.0001$ & $<.0001$ \\
\hline
\end{tabular}

